The Tonadilla in Performance 
The publisher gratefully acknowledges the generous support of the Ahmanson Foundation Humanities Endowment Fund of the University of California Press Foundation.

The publisher gratefully acknowledges the generous support of the Music Endowment Fund of the University of California Press Foundation.

The publisher gratefully acknowledges the generous contribution to this book provided by the Robert U. Nelson Fund of the UCLA Herb Alpert School of Music. 


\section{The Tonadilla in Performance}

Lyric Comedy in Enlightenment Spain

Elisabeth Le Guin

\section{甲}

UNIVERSITY OF CALIFORNIA PRESS

Berkeley Los Angeles London 
University of California Press, one of the most distinguished university presses in the United States, enriches lives around the world by advancing scholarship in the humanities, social sciences, and natural sciences. Its activities are supported by the UC Press Foundation and by philanthropic contributions from individuals and institutions. For more information, visit www.ucpress.edu.

University of California Press

Berkeley and Los Angeles, California

University of California Press, Ltd.

London, England

(C) 2014 by The Regents of the University of California

Library of Congress Cataloging-in-Publication Data

Le Guin, Elisabeth, 1957-.

The tonadilla in performance : lyric comedy in enlightenment Spain / Elisabeth Le Guin.

p. $\mathrm{cm}$.

Includes bibliographical references and index.

ISBN 978-0-520-27630-7 (cloth : alk. paper)

ISBN 978-0-520-95690-2 (ebook)

1. Tonadillas-History and criticism. I. Title.

ML1747.L4 2013

$782.1-\mathrm{dc} 23$

2013014805

Manufactured in the United States of America

$\begin{array}{llllllllll}23 & 22 & 21 & 20 & 19 & 18 & 17 & 16 & 15 & 14\end{array}$

$\begin{array}{llllllllll}10 & 9 & 8 & 7 & 6 & 5 & 4 & 3 & 2 & 1\end{array}$

In keeping with a commitment to support environmentally responsible and sustainable printing practices, UC Press has printed this book on Natures Natural, a fiber that contains $30 \%$ post-consumer waste and meets the minimum requirements of ANSI/NISO Z39.48-1992 (R 1997) (Permanence of Paper). 
In honor of Daniel Heartz, and in memory of Wye Jamison Allanbrook and Robert Murrell Stevenson 
This page intentionally left blank 
Oye atento, y del arte no disputes, que en la comedia se hallará modo que, oyéndola, se pueda saber todo.

Listen well, don't dispute over Art, For just by listening you'll find the way To know all things, for all are in the Play.

- LOPE DE VEgA, NUEVO ARTE DE HAZER COMEDIAS EN ESTE TIEMPO (1609) 
This page intentionally left blank 